\title{
METHODOLOGICAL ISSUES OF FORMING THE PROFITABLE POTENTIAL OF THE REGION
}

\author{
Khotamjon Kobulov \\ Candidate of Economic Sciences, Associate Professor of the Department of Finance \\ Tashkent institute of Finance, Uzbekistan
}

Article DOI: https://doi.org/10.36713/epra6158

\begin{abstract}
The article considers the role and importance, the place of the region's income potential in the general system of financial support of municipalities, discloses the essence of the region's income potential in a wide and narrow sense, studied the mechanism of formation and use of the region's income potential and its elements, quantitative and qualitative expression of this concept on the example of its integral element - "the fiscal tax potential of the region."

KEYWORDS: region, region development strategy, municipalities, local budgets, potential, financial potential of the region, region's revenue potential, region's fiscal tax potential.
\end{abstract}

\section{INTRODUCTION}

"Modern trends in the development of the world economy, measures to smooth out the impact on the economy of the Republic of Uzbekistan of negative external factors, demographic tendency and tensity in the labor market, the necessity to build the production potential of the territories, ensuring employment growth and improving living conditions of the population is considered an important guideline in the comprehensive solution of the issues of transition of the country's economy to the path of sustainable development and improving the welfare of the population"[1].

A new stage of reforming and modernizing the economy of the Republic of Uzbekistan, its integration into the world economy predetermined the need to revise the approach to the selection of new factors for investment and innovation development and create conditions for their use. However, the achievement of sustainable growth based on real restructuring of the economy and improving the competitiveness of domestic goods is constrained by one of the most important constraints for ensuring economic growth and development financial resources, whose role is constantly growing. At the same time, a certain conflict is clearly manifested in the Republic of Uzbekistan - a financial and banking system has been formed that provides the state and economic entities with financial resources, but at the slightest manifestations of risks and threats, this system is destabilized, resulting in a liquidity crisis, a transition to budget deficits, cash outflows from the system and the country, increased inflation, etc. The lack of financial resources is especially acute at the regional level, because, on the one hand, there were negative tendencies and problems in the development of individual regions of the country on the background of increasing economic, social, demographic and environmental imbalances. On the other hand, the regions were drawn into the competition for attracting financial resources in the form of budgetary funds, as well as financial market funds. In this regard, it seems appropriate to take into account not only the factors of economic growth, but also the conditions, mechanisms and tools with which these factors can be combined and most effectively used, i.e. should take into account the growth and development potential of the economy, allowing them to be provided in the long run.

The absence in the regions of an integrated approach to the formation and use of financial flows is determined, first of all, the lack of regional sections in most government documents where financial components are prescribed is limited. In addition, there is an underestimation of certain elements of the region's revenue potential, the main emphasis has been on the formation and use of the fiscal potential while completely ignoring the weak potential of credit and insurance organizations, investment companies and funds, and the population. As a result, the designed regional development programs and strategies are often financially unsecured. 
It is well known that the possibilities of the regions of the Republic of Uzbekistan in the formation of financial potential are different due to climatic conditions, the existing system of division of labor and the structure of the economy, the level of development of production, etc. The current practice of "transferring" from the republican to the regional level the majority of economic problems in the absence of sufficient funding resources in the regions to solve them has further strengthened regional differentiation, weakening the financial opportunities for economic development of the regions. The importance of adjusting the approach to the formation and use of income potential lies in the fact that based on the financial capabilities of the state and all subjects of the region's economy, it is necessary to increase its financial self-sufficiency, as well as the predominant use of private investors. This approach involves the allocation, development and consideration in the formation and implementation of state policy in relation to regions of such aspects as fiscal policy, banking policy, policy on the development of the insurance market, securities market, etc., the constant development which leads to a deformation of the structure and composition of the revenue potential, the magnitude and role of which is not sufficiently taken into account when developing a regional development strategy.

\section{MAIN PART}

According to Vlasova, A.I. "The revenue potential of the regions requires more active implementation of public-private partnerships, facilitate business as much as possible by introducing tax incentives and accelerating and simplifying bureaucratic procedures, a decrease in the share of unproductive expenses and an increase in productive expenses, which will lead to an increase in the effectiveness of the budget policy of the region. A comprehensive solution to increasing the revenue potential of the regions at present will lead to a powerful positive effect for the entire economy of the region in the long term"[2].

Seleznev and Dotsenko believe that "an important macroeconomic task is the" system of generating regional budget revenues in connection with the acute problem of a real deficit in financing regions "[3].

Serebryakova noted, "Financial support of municipalities as one of the most complex and pressing issues of local government reform" [4].

The lack of a single conceptual apparatus of the essence of the "revenue potential", which is identified by most scientists with investment or budget potential; its elements, as well as the relationships between them, complicates the process of its formation, use and building. It is important to note that the "profitable", "financial" and "investment" potentials are independent categories, differing in terms of input elements, impact mechanism, etc., however, to some extent, they intersect - the investment potential partially includes financial, and financial potential - part of the resources allocated for investment.

The region's income potential in the broad sense should be defined as the ability of the region's financial system to ensure growth and development in the long term due to the combination of the maximum available resources, as well as the conditions (mechanisms and tools) created by the state, organizations and households of the region for the formation, distribution and use these resources in order to achieve certain financial results, ensure expanded reproduction and social development.

Herewith, followings should be provided: the availability of own sources of financing that ensure the basic needs of the region; the ability to attract external sources in the required volumes on acceptable terms; formation of resources at an acceptable level of risk; the presence of institutions that ensure the effectiveness of financial management in the region.

In the narrow sense of the term, the income potential of the region is understood to mean the totality of the revenue sources received by the subjects of the financial system necessary to ensure simple reproduction of improving the quality of life in the region (i.e., the potential used).

For a clearer analysis, we have proposed an extended classification of the revenue potential, taking into account sets of parameters. In this case, two approaches can be taken into account: process and elemental. From the point of view of the process approach, we propose to extract following components of the revenue potential: resources created during this period; borrowed resources and accumulated resources. Such categories as finance, financial resources, subjects of the financial system, financial policy, etc., should be extracted as system elements of the revenue potential.

In general form, the mechanism for the formation and use of revenue potential includes followings:

- a set of principles on the basis of which the formation and implementation of potential takes place - a systematic approach, taking into account the characteristics of the region, the continuity of the process of formation and management of potential, self-sufficiency, the relationship of potential elements, improving financial relations, the accumulation and use of financial resources, the transparency of the processes of formation and use of resources and potential, public-private partnership in the field of resource formation, minimization of possible risks, etc .;

- The totality of financial instruments credits, loans, bonds, taxes, etc .;

- a set of financial assessment methods calculation of coefficients, factor analysis, valuation, normative, deviation analysis, etc. 
- The region's income potential is quantified as a result of the interaction of such elements as the potential of enterprises and organizations, fiscal tax potential, potential of credit institutions, potential of insurance companies, potential of investment companies and funds, potential of households. It is necessary to consider that the revenue potential is the result of the activities of both a separate economic entity, so the region and the country as a whole; it is a prerequisite for ensuring the economic security of the country and its territories; characterizes the ability of the region to create in a sufficient quantities of the financial resources it needs; characterizes the level of development of the financial and banking system of the region; it is a measure of the effectiveness of the activities of regional governing bodies and authorities; represents the result of harmonization of the goals and interests of the state, region and its subjects; reflects, on the one hand, the existence of threats to socio-economic development, and, on the other, the region's ability to counter emerging risks and threats. In addition, It is necessary to consider that the parameters of financial potential are an information system for the development and implementation of the strategy of socio-economic development of the state and its individual region.

- The revenue potential is being realized in order to provide the regions with the necessary financial resources; stimulating economic entities to increase financial inflows; redistribution of resources between the subjects of the financial system of the region, as well as in favor of the republican center; control over the process of formation, distribution and use of financial resources; insurance against possible threats. The role of assessing income potential in the process of developing and implementing a strategy for socio-economic development is determined by the mechanism for making strategic and operational decisions that ensure the sustainability and stability of the socioeconomic development of the region (Fig. 1). In this case, on the one hand, the revenue potential characterizes the possibility of realizing the development goals of the region, and on the other hand, the value of the potential depends on the effectiveness of their implementation. 


\section{Regional Development Strategies}

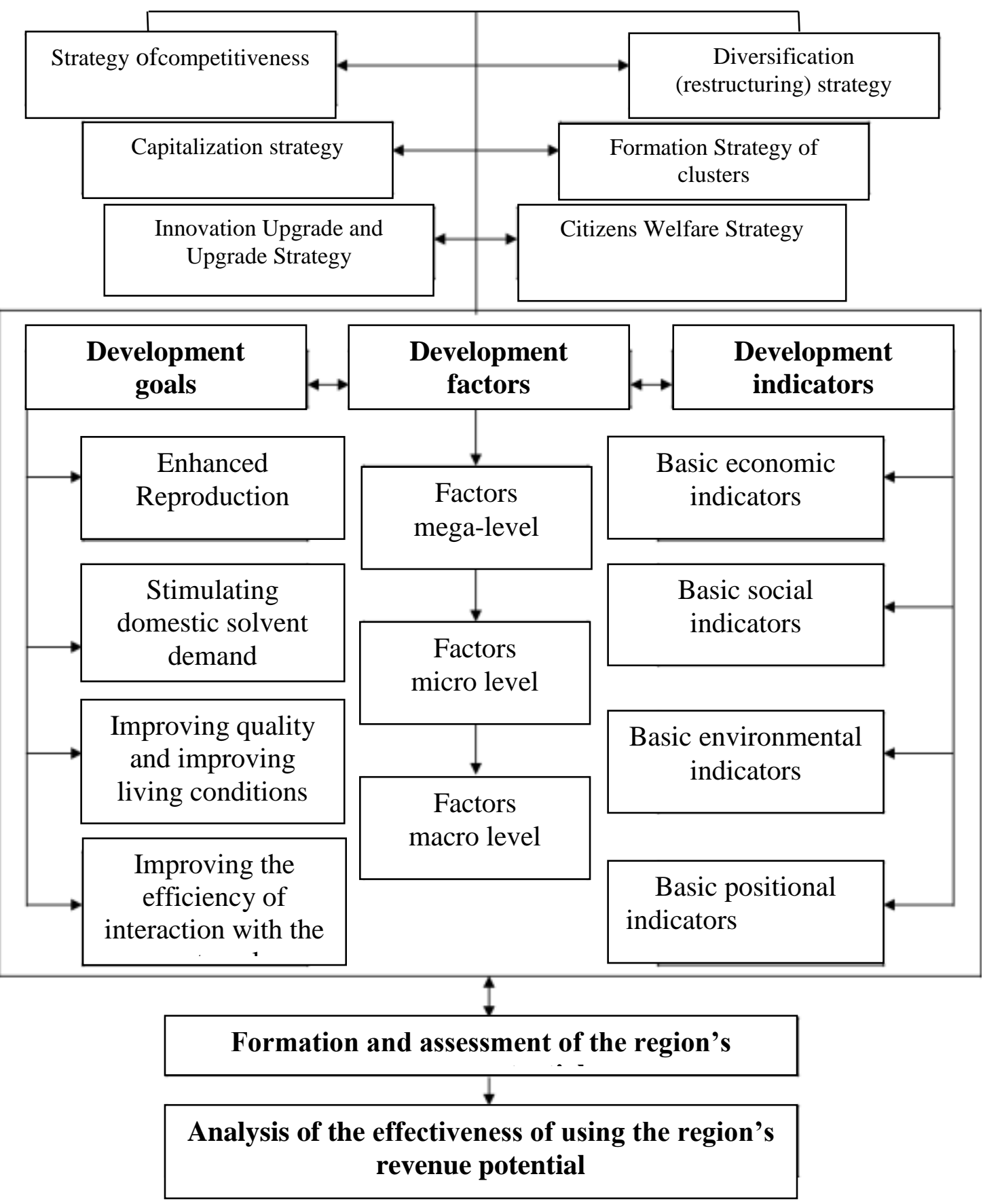

Fig. 1. The role of revenue potential in achieving sustainable development of the region

For a clear reasoning of the methodology for determining the region's income potential, we consider one of its structural elements - the fiscal tax potential of the region using the coefficients of the fiscal potential of the region (table-1).

The fiscal potential of the region (PF) in absolute terms represents the amount of funds raised by local budgets and extra-budgetary funds:

$$
\mathbf{P F}=\mathrm{TP}+\mathrm{NTP}+\mathrm{TP},
$$

TP - tax sources formed by the region;

NTP - non-tax sources attracted by the region; $\mathrm{TP}$ - interbudgetary transfers. 
Table 1

Table of coefficients of the fiscal potential of the region [6]

\begin{tabular}{|c|c|c|c|c|c|}
\hline \multirow[b]{2}{*}{ Indicators } & \multicolumn{5}{|c|}{ Potential level } \\
\hline & High & $\begin{array}{l}\text { Higher } \\
\text { Than } \\
\text { Middle }\end{array}$ & Middle & $\begin{array}{l}\text { Below } \\
\text { Middle }\end{array}$ & Low \\
\hline $\begin{array}{l}\text { Coefficient of coverage of expenses as a ratio of } \\
\text { own budget revenues of the region to its total } \\
\text { expenses }\left(C_{1}\right)\end{array}$ & $>1,0$ & $0,75-1,0$ & $0,5-0,75$ & $0,25-0,5$ & $<0,25$ \\
\hline $\begin{array}{l}\text { Coefficient of the concentration of own income } \\
\text { as the ratio of own budget income to the total } \\
\text { income of the region }\left(C_{2}\right)\end{array}$ & $>0,8$ & $0,6-0,8$ & $0,4-0,6$ & $0,2-0,4$ & $<0,2$ \\
\hline $\begin{array}{l}\text { Coefficient of provision of the population with } \\
\text { own incomes as the ratio of the value of the } \\
\text { region's own incomes per capita to the } \\
\text { country's own income per capita }\left(C_{3}\right)\end{array}$ & $>2$ & $1,5-2,0$ & $1,0-1,5$ & $0,5-1,0$ & $<0,5$ \\
\hline $\begin{array}{l}\text { The ratio of region's own revenues to the } \\
\text { amount of budget transfers }\left(C_{4}\right)\end{array}$ & $>4,0$ & $3,0-4,0$ & $2,0-3,0$ & $2,0-1,0$ & $<1,0$ \\
\hline
\end{tabular}

In addition to the absolute value, we propose to evaluate the level of the fiscal potential of the region based on a combination of indicators (Table 1). Quantify the level of fiscal potential and you can rank the regions using the $\mathrm{C}_{\text {integr. }}$ integral indicator calculated by the formula:

$$
\mathrm{C}_{\text {integr. }}= \pm \sqrt[4]{\sum_{i=1}^{4} \mathrm{PC}_{i}}
$$

$\mathrm{C}_{\mathrm{i}}$ - individual indicators characterizing the fiscal potential $-\mathrm{C}_{1}, \mathrm{C}_{2}, \mathrm{C}_{3}$ and $\mathrm{C}_{4}$.

Depending on the value of the integral indicator, it will be possible to establish the aggregate level of the fiscal potential of the region:

at $\mathrm{C}_{\text {intgr. }} \geq \mathbf{1 . 6}$ the potential of the region can be considered high;

at $1.2 \leq \mathrm{C}_{\text {intgr. }}<1.6$ - above average;

at $0.8 \leq \mathrm{C}_{\text {intgr. }}<1.2$ - average;

at $0.4 \leq \mathrm{C}_{\text {intgr. }}<0.8$ - below average;

at $\mathrm{C}_{\text {intgr. }}<0.4$ - low.

\section{CONCLUSION}

1. The lack of a single conceptual apparatus and a single theoretical approach to the allocation of elements of the region's revenue potential hinders the possibility of its formation and growth. The region's revenue potential in the broad sense can be defined as the totality of the maximum possible financial resources, as well as the conditions for their involvement, created by the state and regional economic entities for the formation, distribution and accumulation of these resources in order to ensure long-term growth and socio-economic development, to achieve certain financial results.

2. It is advisable to extract such potential components as fiscal tax, credit organizations, enterprises and organizations, investment companies and funds, households as elements of the revenue potential, in relation to each element, it is necessary to assess the absolute and relative values, as well as identify risks that determine decrease in potential value.

3. When developing a development strategy for a region, it is necessary to take into account the size of its investment and financial potentials. At the same time, such stages as identification of the region should be highlighted; assessment of the state of production, natural resource, labor, innovative potentials; identification of external and internal factors and threats to economic growth, both quantitative and qualitative; assessment of the financial potential of the region and preparation of a report on its condition; analysis and assessment of investment needs and the investment climate of the region; analysis of the results of using the investment potential of the region and assessment of investment management in the region, development of a development strategy for the region, which should be linked to the country's development strategy.

4. Taking into account the constant changes in the external and internal environment, it is necessary to develop a mechanism for managing the region's revenue potential, providing for the management of its formation, use and expansion, as well as the management of financial relations and emerging risks and threats. It should be based on interconnected and interdependent principles: synchronized development of macro-, meso- and micro-levels; adaptation to environmental changes; strategic flexibility; public-private and social partnerships; accumulation of temporarily free financial resources; economic security; stimulation; transparency. 


\section{REFERENCES}

1. Decree of the President of the Republic of Uzbekistan No. 5614 dated January 8, 2019 "On the concept of integrated socio-economic development of the Republic of Uzbekistan until 2030".

2. Власова Ю.А., Абрамова А.И. Проблемы укрепления доходного потенциала региональных бюджетов в России на примере Калужской области // Креативная экономика. (№ 10 / 2015), c.34-39.

3. Селезнев А., Доценко Н. Доходный потенциал регионов и его общегосударственное значение // Экономист. - 2016. - N 9. - С. 12-22.

4. Серебрякова О. В. Финансовая стабильность муниципальных образований как приоритет в развитии бюджетной и налоговой политики на местном уровне // Региональная экономика: теория и практика. - 2017. - N 11. - C. 126-131.

5. Вохобов А.В., Жамолов Х.Н. Согласование межбюджетных отнотений // Учебное пособие. Ташкентский финансовый институт, Ташкент, 2002. -239c.

6. Кобулов Х.А. К методологическим вопросам формирования доходного потенциала региона // «Интернаука»: научный журнал - № 16(145). Часть 2. Москва, Изд. «Интернаука», 2020. - с. 91-95 